\title{
Selected Changes in the Microclimate Parameters inside the Large-Volume Buildings Caused by the Heat Emission from People
}

\author{
Paweł Albert Jelec \\ Faculty of Biology and Environmental Sciences, Cardinal Stefan Wyszyński University in Warsaw, Woycickiego street 1/3, Warsaw \\ 01-938, Poland
}

\begin{abstract}
The paper shows selected aspects of the microclimate change inside the selected type of the large-volume buildings-sacral buildings and for comparison —in the residential apartment buildings, caused by the heat emitted by people. Microclimate parameters such as air temperature or air relative humidity change because of heat emission from people staying inside there. Exemplary methods and results of research conducted in the existing sacral buildings and in the residential apartment buildings are shown. It is based on author's research, whose novelty is the research of the human heat emission in case of a big number of people staying inside a large-volume building. It can be useful for sacral buildings and other large-volume buildings design and for a microclimate shaping. In some large-volume buildings as the sacral buildings with a big number of people staying inside at the same time heat emitted from people significantly influences on a microclimate. Human heat streams can be useful as a part of the heat balance of the room.
\end{abstract}

Key words: Microclimate, human heat emission, large-volume buildings.

\section{Introduction}

The heat emitted by people staying inside room can be often considered as useful additional heat streams in some large-volume buildings like the sacral buildings. Those heat gains are considerable as a part of the room heat balance. There are specific conditions in the sacral buildings. Their volume of the room and the floor area is often large, so that staying of big number of people inside room is possible. Very often churches and especially their main nave are tall. People stay all time in the same place and their physical activity doesn't change significantly during Mass. Calculating the heat emitted by people in such circumstances is possible and those heat streams are the important part of a room heat balance and can be predicted in the design phase (considering heating and ventilation systems). So, here are shown exemplary

Corresponding author: Paweł Albert Jelec, Ph.D., Eng., research fields: heat emission from people, large-volume buildings and energy efficiency. results of author's research conducted in the sacral buildings as the exemplary and representative type of objects where a big number of people are equally staying inside room and for comparison in the residential apartment buildings. The main aim was to test the influence of the human heat emission on the microclimate of those types of buildings. Also, the aim was to check whether there is such an increase in internal temperature due to the human heat emission of people, which does not deteriorate the selected microclimate parameters and is important from the point of view of energy efficiency.

The regulation of a blood supply to the skin is the basis of heat exchange between the environment and the man, also inside the rooms and large-volume buildings. Enlargement of the blood vessels results in better blood supply and increases skin surface temperature and it can also take place in the opposite direction because of external heat influence on a skin. The blood can be transferred from the skin to the inside of the body in this case. Typically, resting man 
emits sensible heat (79\%, by convection and radiation) and latent heat (21\%, by evaporation and respiration). Human emission of heat depends on physical activity, gender, clothing, and other factors also. Resting metabolism occurs when the person is resting, lying down, in complete physical and mental calm, more than 12 hours after the last meal, in neutral ambient temperature $\left(16 \sim 20{ }^{\circ} \mathrm{C}\right)$ and it is about $1,163 \mathrm{~W} / \mathrm{kg}$ (mass of the human body) [1]. At the exemplary temperature of $8{ }^{\circ} \mathrm{C}$, possible for the unheated churches, the calculated heat stream is about $370 \mathrm{~W} / \mathrm{m}^{2}$ (area of a body surface) (basing on P. O. Fanger's method) [1] and $193 \mathrm{~W} / \mathrm{m}^{2}$ (J. A. Pogorzelski's method) [2]. At the air temperature of $16{ }^{\circ} \mathrm{C}$, just for comparison, it is $243 \mathrm{~W} / \mathrm{m}^{2}$ [1] and $150 \mathrm{~W} / \mathrm{m}^{2}$ [2]. In case of resting in a laying position, the average internal heat stream from man is about 70-93 $\mathrm{W}$, in sitting position - 81 105 and in staying position it is about 93-128 W [3]. The final two cases are representative of the churches. Calculating of human heat gains is the most important especially in those churches which are unheated. In case of air quality deterioration, the thermal regulation metabolic processes of the human body adapt to the ambient air temperature and air humidity and also human body reacts to the surrounding surfaces temperatures. In the sacral buildings, the big number of people is staying in the room so a human heat emission is multiplied and it causes an increase in the air temperature. So, the main question of the research is if it is possible to treat human heat emission as a useful heat gain in such buildings when a big number of people are staying without air quality deterioration. Such deterioration is observed in residential apartment buildings, where it often leads to serious troubles. In the paper, here are presented some exemplary results of research and some comparison of the mentioned above types of large-volume buildings.

\section{Materials and Methods}

\subsection{Research Description}

The research on the sacral buildings had started in the year 2000 at the Warsaw University of Technology (under the scientific supervision of Prof. Leszek Wolski). All tested buildings were located in the Masovian Voivodeship in Poland. It is now continued by author at the Faculty of Biology and Environmental Sciences of the Cardinal Stefan Wyszyński University of Warsaw in the Department of Environmental Engineering. Next, the research at the residential apartment buildings has started in 2014. The tested buildings are the residential apartment buildings and also the single-family residential buildings.

Research on all types of large-volume buildings mentioned above is still ongoing.

\subsection{Objects Location}

The tested sacral large-volume buildings were located in the town of Płock and the Masovian Voivodeship in Poland and they were 18 large-volume buildings with at least one large-volume room. During the research there were about 300,000 data achieved, 1,200 photos registering people staying inside buildings and a few thousands of thermal images (also for the residential buildings, including buildings affected by the sick building syndrome in which mold occurs). For the data analysis, there used a special dedicated software-program "MAPKALK".

\subsection{Tested Objects Characteristics}

In the aim of evaluation of the human heat emission influence on the microclimate, three distinct types of sacral buildings have been identified. They have selected 9 from the group of 18 tested objects. All selected sacral buildings were located in the city of Płock. The tested residential buildings were located in the Płock, Ciechanów, and Płońsk districts (Masovian Voivodeship).

The selected sacral buildings are shown below:

Object 1: Chappel "Kaplica Rzymskokatolickiej Parafii pw. Ducha Świętego", Płock, contemporary construction. 
Object 2: Church "Kościół pw. św. Józefa”, Płock, contemporary construction.

Object 3: Church "Kościół pw. św. Krzyża”, Płock, contemporary construction.

Object 4: Church "Kościół pw. św. Stanisława Kostki” (lower), Płock, contemporary construction.

Object 5: Church "Kościół farny pw. św. Bartłomieja”, Płock, contemporary construction.

Object 6: Church "Kościół pw. św. Jana Chrzciciela", Płock, 18th century construction.

Object 7: Church "Kościół rzymsko-katolicki pw. św. Stanisława Kostki" (upper), Płock, contemporary construction.

Object 8: Cathedral Basilica: "Bazylika Katedralna pw. Wniebowzięcia Najświętszej Maryi Panny”, Płock, 11th century construction.

Object 9: Church "Kościół Matki Boskiej Częstochowskiej”, Płock, contemporary construction.

Types of objects were classified by their volumes:

Type I (small): Volume range: 1,413 2,760 $\mathrm{m}^{3}$, height range in the middle part of the room: $3.7 \sim 8.5 \mathrm{~m}$ (objects 1, 2, 3).

Type II (medium): medium-volume objects and average height. Volume range: 3,451 6,000 $\mathrm{m}^{3}$, height range in the middle part of the room: $5.8 \sim 12 \mathrm{~m}$ (objects 4, 5, 6).

Type III (large): large-volume and significant height objects. Volume range: 17,218 34,058 $\mathrm{m}^{3}$, height range in the middle part of the room: 12 26.5 m (objects 7, 8, 9).

\subsection{Measuring Points Location}

In the aspect of air temperature and relative humidity measurements, thermohygrometers were placed at different heights in the building at fixed measuring points (also hanged) or on the portable tripods staying on the floor. In the case of measurements made at the points located at the significant height, there used the original author's method of using balloons with helium to hang the ropes on construction elements in the room such as tie rods on which the measuring devices later were mounted. Measuring points were located in the different points of the church nave space, depending on its layout and the possibility of probe location. So, at objects $1,2,3,5,8$ and 6 it was located along the walls and the benches (Fig. 1a) and in the objects 4, 9 and 7, because of their round shape, measuring points were located in more irregular and “dispersed” points (example is shown in Fig. 1b). In those points, there were a mounted or portable thermohygrometers: on tripods, portable poles or suspended on ropes attached to the tension rod or another existing rod (basing on author's method). It is shown in Fig. 2 (case "c"-mounting rods for the chandelier suspension were used there to attach the ropes). Objects, number of points, and location of the measuring points over the level of the floor are listed below:

- Object 1, Points: 1-9, Heights: 0; 1; 1,8; 2,6; 5,2;

- Object 2, Points: 1-9, Heights: 0,7; 2; 4;

- Object 3, Points: 1-8, Heights: 1, 2, 3, 4;

- Object 4, Points: 1-7, Heights: 1, 2, 3, 4, 5;

- Object 5, Points: 1-9, Heights: 0,1; 1; 2; 3; 4;

- Object 6, Points: 1-10, Heights: 0, 1, 2, 3, 4, 6, 9, 12 ;

- Object 7, Points: 1-9, Heights: 0, 1, 2, 3, 4, 5, 6, 7, 8 ;

- Object 8, Points: 1-9, Heights: 0,1; 1, 2, 3, 4, 6, 8, 11 ;

- Object 9, Points: 1-8, Heights: 0, 1, 2, 3, 4.

At the residential buildings, measurements were performed in the occupied zone in the different points of the rooms. In case of thermal images, they were made for the selected surfaces of the partitions.

\subsection{Specific Formal Aspects of the Research Methodology}

During the research, there were used the requirements of the polish standard PN-EN 13187 [4] (Polish version of the European standard EN 13187:1999 “Thermal performance of buildings-Qualitative detection of thermal irregularities in building envelopes-Infrared 


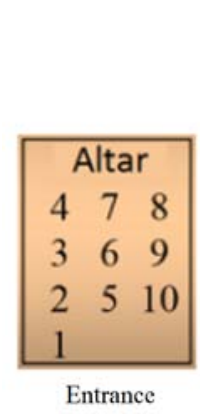

(a)

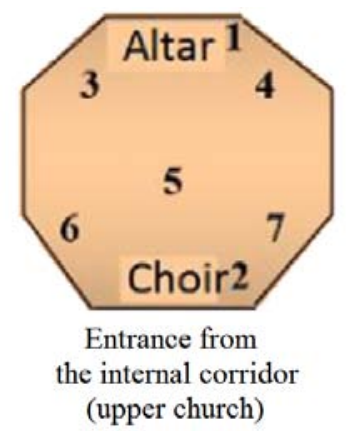

(b)
Fig. 1 Typical measuring points location: object 6 (a) and 7 (b).

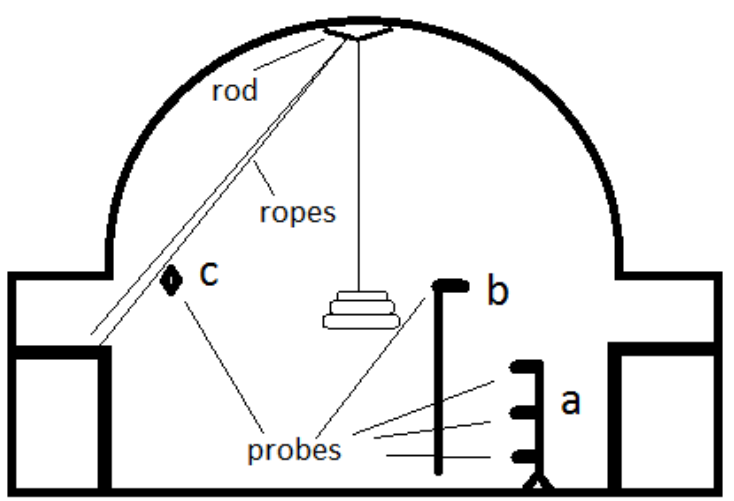

Fig. 2 The types of the measurements with the use of the thermohygrometers: probes mounted on tripods (a), portable poles (b) or suspended on ropes fixed to the existing rods mounted under the ceiling (c).

method"). Research met the requirements of Polish civil engineering law for buildings and their location [5] and requirements of many European Standards, such as PN-EN ISO 6946:2017-10 [6], PN-EN 12831-1:2017-08 [7].

\section{Results and Discussion}

Below the selected results of the research performed inside sacral buildings of three types are presented (some of those results were also publicated by authors in Refs. [8-11]. Additionally, those buildings are compared to the residential apartment buildings in the selected aspects of the influence of the heat emission from people on the microclimate. The tested sacral buildings of a large volume were generally unheated or poorly heated. The analyzed cases are those for which the temperature rise during people's stay is significant (not less than $0.5^{\circ} \mathrm{C}$ ) and the impact of external climatic conditions can be assessed as negligible. This allowed analyzing those cases which deserve attention. In those cases, the heat from humans is a major cause of the increase in indoor air temperature.

\subsection{Air Temperature and Air Relative Humidity Changes}

Within the scope of the research, measurements have been made in the objects of the three types (I, II III), described earlier in the subsection 2.3. The space of the tested rooms was divided into zones. These zones (shown in Fig. 3 and in Tables 1 and 2) are: "mean"-those are mean results from the whole space of the room (on the selected height over the floor), "center"-means strictly the central part of the room, "edges"-denotes the area along the walls. The analysis was made also in the zone named "extended center"-it denotes the middle part of the room, and "ext. mid. with. cent." - which means the middle part of the room, excluding its strictly central part. The space of the room is divided into the flat planes laying on the fixed height over the level of the nave floor. Presented results illustrate the results obtained from hundreds of measurements made in many objects grouped into the three discussed types of sacral buildings. The high number of persons staying in Type III (large) objects is the least obvious and repeatable, due to the large space available for staying as well as due to the different architectural features of objects. There is generally greatest density of settlement in Type I objects. It is profitable from the point of view of a thermal comfort. In addition, the highest air temperature after Mass is observed in Type I objects, which results from the smaller volume and height of objects with a relatively large number of occupants and a relatively high settlement coefficient (as a number of people referring to the area they are staying in). Type I objects, due to the smaller volume and height of the objects, achieve a more uniform 


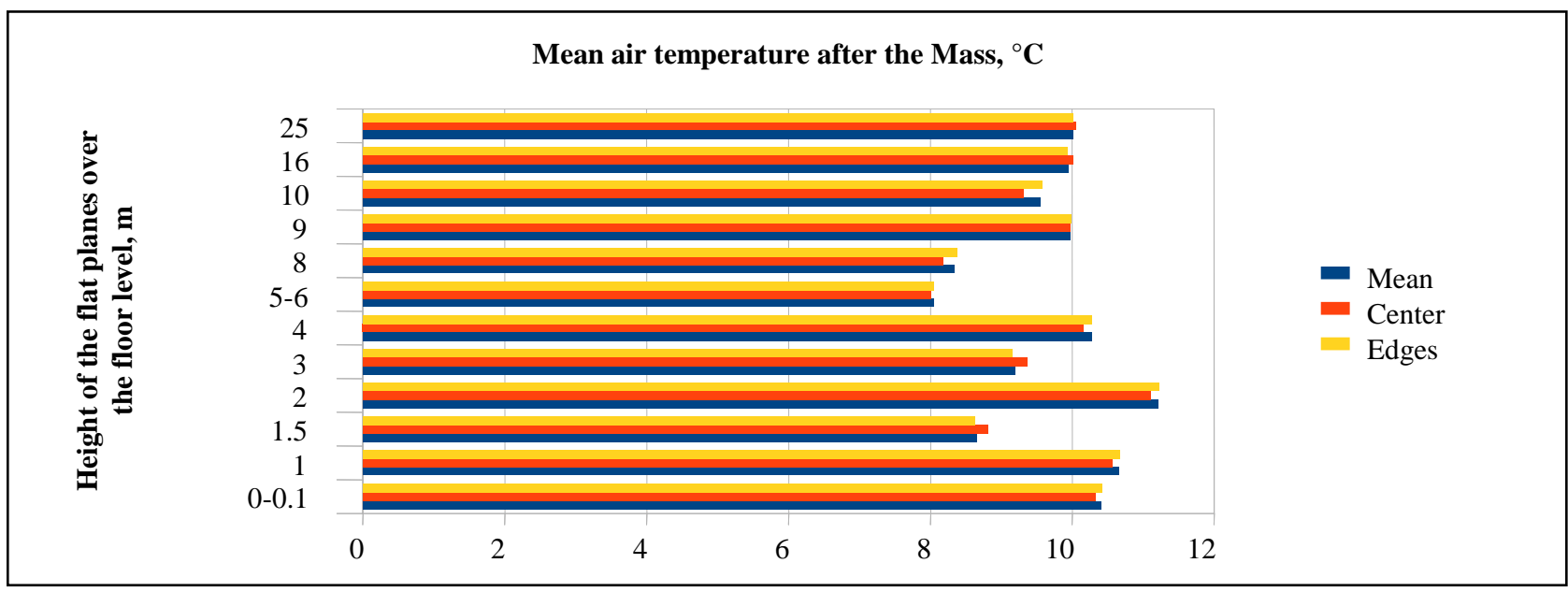

Fig. 3 Mean air temperature rise after the Mass, in Type III objects, ${ }^{\circ} \mathrm{C}$.

Table 1 Mean air temperature increases.

\begin{tabular}{|c|c|c|c|c|c|c|c|}
\hline \multirow{5}{*}{$\begin{array}{l}\text { Small objects } \\
\text { (Type I) }\end{array}$} & & & \multicolumn{5}{|c|}{ Zone } \\
\hline & & & Mean & Center & Edges & Extended center & $\begin{array}{l}\text { Ext. mid. with. } \\
\text { cent. }\end{array}$ \\
\hline & \multirow{3}{*}{$\begin{array}{l}\text { Type of a } \\
\text { value }\end{array}$} & Min. & 1.593 & 1.525 & 1.571 & 1.365 & 1.325 \\
\hline & & Mean & 2.144 & 1.908 & 2.146 & 1.958 & 1.946 \\
\hline & & Max. & 2.967 & 2.308 & 3.150 & 2.439 & 2.433 \\
\hline \multirow{5}{*}{$\begin{array}{l}\text { Medium objects } \\
\text { (Type II) }\end{array}$} & & & \multicolumn{5}{|c|}{ Zone } \\
\hline & & & Mean & Center & Edges & Edges & $\begin{array}{l}\text { Ext. mid. with. } \\
\text { cent. }\end{array}$ \\
\hline & \multirow{3}{*}{$\begin{array}{l}\text { Type of a } \\
\text { value }\end{array}$} & Min. & 0.839 & 0.850 & 0.920 & 0.870 & 0.909 \\
\hline & & Mean & 1.190 & 1.102 & 1.204 & 1.155 & 1.176 \\
\hline & & Max. & 1.519 & 1.450 & 1.458 & 1.470 & 1.700 \\
\hline \multirow{5}{*}{$\begin{array}{l}\text { Large objects } \\
\text { (Type III) }\end{array}$} & & & \multicolumn{5}{|c|}{ Zone } \\
\hline & & & Mean & Center & Edges & Edges & $\begin{array}{l}\text { Ext. mid. with. } \\
\text { cent. }\end{array}$ \\
\hline & \multirow{3}{*}{$\begin{array}{l}\text { Type of a } \\
\text { value }\end{array}$} & Min. & -0.056 & 0.000 & -0.075 & -0.033 & -0.060 \\
\hline & & Mean. & 1.716 & 1.755 & 1.831 & 1.886 & 1.711 \\
\hline & & Max. & 6.340 & 5.820 & 6.337 & 7.511 & 6.393 \\
\hline
\end{tabular}

Table 2 Mean air relative humidity increase.

\begin{tabular}{|c|c|c|c|c|c|}
\hline \multirow{5}{*}{$\begin{array}{l}\text { Small objects } \\
\text { (Type I) }\end{array}$} & & & \multicolumn{3}{|c|}{ Zone } \\
\hline & & & Mean & Center & Edges \\
\hline & \multirow{3}{*}{$\begin{array}{l}\text { Type of a } \\
\text { value }\end{array}$} & Min. & 5.429 & 5.393 & 5.423 \\
\hline & & Mean & 10.418 & 9.582 & 10.444 \\
\hline & & Max. & 15.881 & 15.227 & 15.876 \\
\hline \multirow{5}{*}{$\begin{array}{l}\text { Medium objects } \\
\text { (Type II) }\end{array}$} & & & \multicolumn{3}{|c|}{ Zone } \\
\hline & & & Mean & Center & Edges \\
\hline & \multirow{3}{*}{$\begin{array}{l}\text { Type of a } \\
\text { value }\end{array}$} & Min. & 2.228 & 3.042 & 2.590 \\
\hline & & Mean & 3.808 & 4.213 & 3.861 \\
\hline & & Max. & 5.059 & 5.569 & 5.073 \\
\hline \multirow{5}{*}{$\begin{array}{l}\text { Large objects } \\
\text { (Type III) }\end{array}$} & & & \multicolumn{3}{|c|}{ Zone } \\
\hline & & & Mean & Center & Edges \\
\hline & \multirow{3}{*}{$\begin{array}{l}\text { Type of a } \\
\text { value }\end{array}$} & Min. & 1.280 & 0.665 & 3.352 \\
\hline & & Mean & 3.702 & 3.003 & 4.397 \\
\hline & & Max. & 5.794 & 4.343 & 6.500 \\
\hline
\end{tabular}


temperature distribution in the vertical section of the room. In the large objects (Type III) the most characteristic vertical profile temperature is observed. Evident convective upward flow is observed especially in this type of buildings. A similar situation is observed also in Type II objects. Type III objects are characterized by considerable height (the charts scales reach $28 \mathrm{~m}$, but in some cases rooms even reach the height of more than $30 \mathrm{~m}$ ). For convective heat transfer, the curvature of the graph and the higher temperature at a certain height (from about 15 to $25 \mathrm{~m}$ ) are observed, followed by a slight reduction in the air temperature near the ceiling (as a result of heat transfer to the outside through the partition). There is a significant increase in air temperature in the human occupation zone up to an average of about 10.5 ${ }^{\circ} \mathrm{C}$ in rooms where the initial temperature is around $6 \sim 8{ }^{\circ} \mathrm{C}$.

The similar convective move of the air to the ceiling especially in Type II and Type III objects is observed (some air temperature lowering in the medium height range is visible in Fig. 3 in Type III objects). Tables 1 and 2 show the brief conclusions concerning increase in air temperature (Table 1) and relative humidity (Table 2) in the tested objects of the three selected types. The air temperature increases shown in Table 1 are important for microclimate and thermal comfort of the large-volume sacral building, especially if it is unheated. In practice, this allows for self-heating of many sacral buildings, especially those of a smaller volume. For small objects although, there is often a risk of excessive air humidity, which requires adequate ventilation. But usually, sacral objects are intensively ventilated between the Masses.

\subsection{The Settlement Coefficient and Its Influence on the} Heat Streams

In the churches, especially those of modern design and architectural form, there are many different constructional solutions and therefore there are different heights and volumes. So, there are small churches (300 to 600 of Mass attendees) and even very large (3 6 thousand of persons staying during Mass). There are also different proportions of seats to the standing places. It is possible to obtain a relatively high density of settlement (in case of standing position), in the order of $2.8 \sim 3.0$ persons $/ \mathrm{m}^{2}$. In the sacral buildings, there are lowest values of the settlement coefficient on weekdays in the morning and in the afternoon. The highest person numbers (full use of the area of the floor) are observed at high Mass on Sundays. The settlement coefficient almost does not change during the Mass (Fig. 4). It is important for the possibility of the heat gain calculation.

Entering the building by people starts about 15-20 minutes before the Mass (Fig. 5) and they leave it maximally about 5 minutes after the Mass. The settlement coefficient assumes the highest values in the area being nearest to the altar (middle part). First, the Mass attendees in general cases are occupying seating places at the benches, and next, the standing places.

At the residential apartment buildings there completely different situation and a heat streams from people are divided into the rooms (opposite case is the sacral buildings where they are generally accumulated in one room-nave). The density of the settlement is quite different-it is typically from 1 to $4 \sim 5$ persons leaving at the different rooms, which additionally depends on the specific inhabitants behavior.

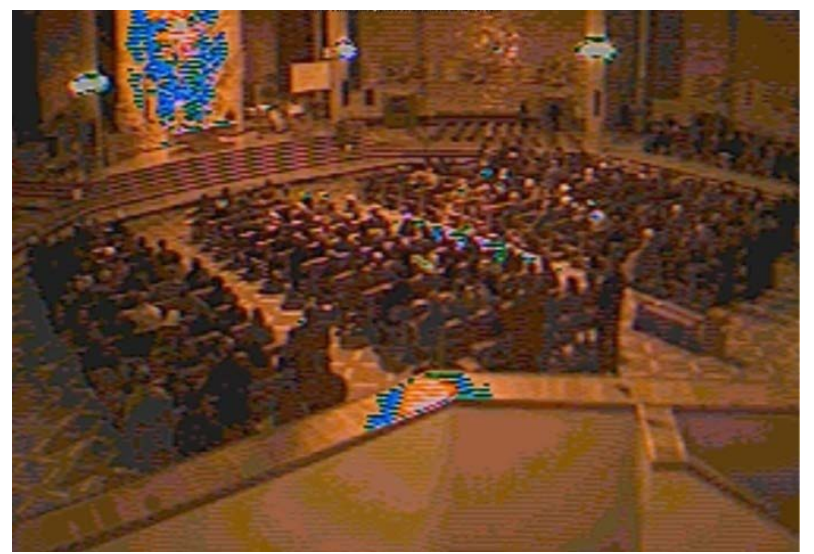

Fig. 4 Settlement structure. State during the Mass (6:05 PM). Sitting position. Object 7. 


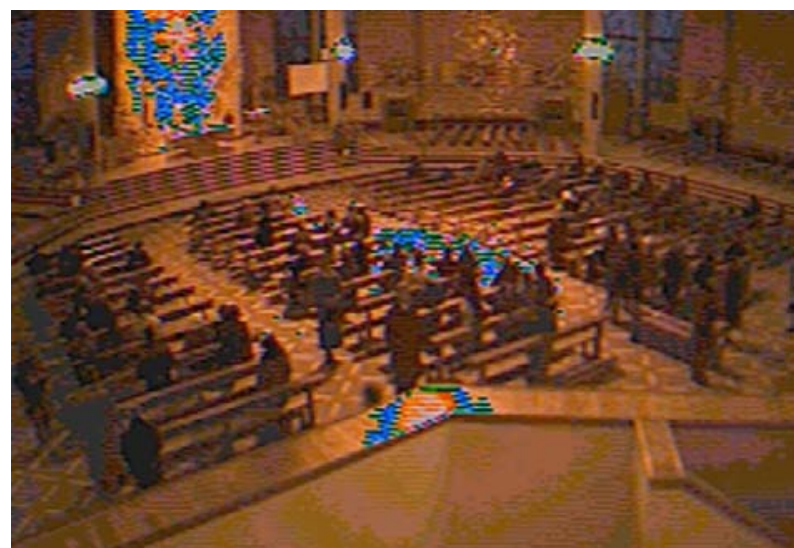

Fig. 5 Settlement structure. State before the Mass (5:47 PM). Entering the church by people. Object 7.

Fig. 6 shows the direct correlation between a number of persons staying in the room and expected effect as the air temperature increases. In Fig. 6 there are two different heights over the level of the floor and some exemplary predicted air temperature increases for Object 7.

Sacral buildings often do not achieve the normative air temperature of thermal comfort. A low number of people staying in the sacral building during the test cause relatively low human heat gain.

It does not affect significantly the microclimate. Another obvious reason that the thermal comfort is often not achieved is the very low initial air temperature in the churches. In objects where the big number of people is staying there sometimes are significant increases in air temperature leading to achieving thermal comfort. Additionally, the cumulative effect of successively air temperature increase occurs sometimes (on Sundays) because of low intervals between the Masses. Particular attention could be paid to small objects, where the increase in the air relative humidity due to the presence of people in the object reaches up to about a dozen percent (in the case of long people's stay in successive Masses). In the aspect of objects comparison, there is a different situation than in another category of objects: apartment residential buildings. There are a large number of people staying in the residential building a long time, but the total heat gains from people are divided into individual dwellings and distributed in the many rooms.

In the tested apartment residential buildings, the heat gains from people were often the reason for significant humidity increases. Adequate infiltration of external fresh air and proper ventilation were necessary there to achieve a right quality of the inner air. In some tested cases, ventilation was insufficient and led to serious troubles with this inner air quality. In the sacral buildings, the large volume of the objects (especially Type II and Type III) in a certain way causes that often adequate air quality is provided. The ventilation needs are much smaller there than in

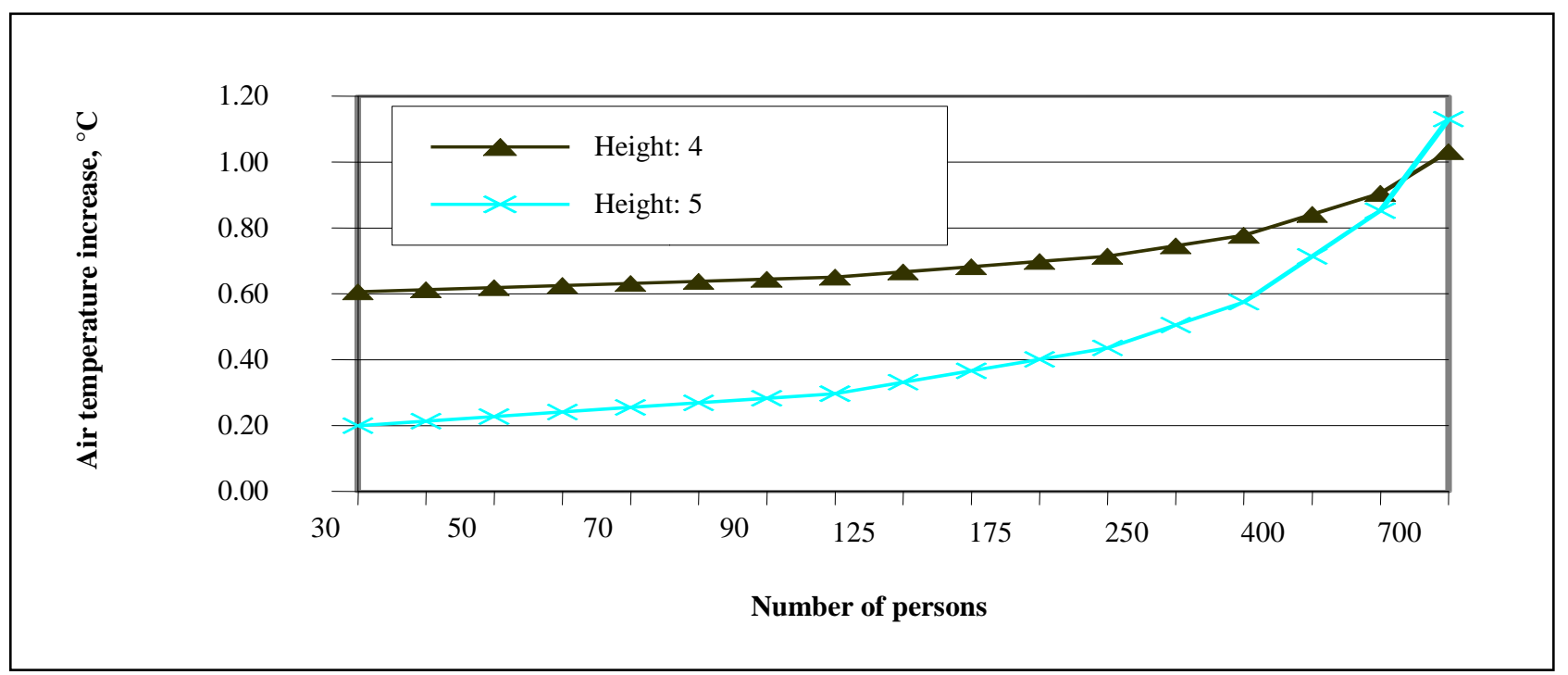

Fig. 6 Air temperature increase inside Object 7 depending on the number of persons (Type II-medium object). 


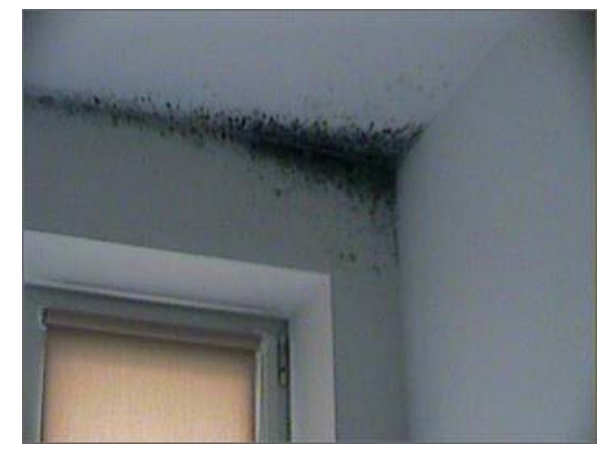

Fig. 7 Exemplary detected troubles in the tested residential apartment buildings: mold in the room corner, on the internal surface of the external wall.

residential apartment buildings and sacral buildings of Type I. Nevertheless, the human-derived moisture gains often contribute (in conjunction with other factors) even to the sick building syndrome and mold (example in Fig. 7). In considerable cases, it was caused by poor ventilation, limited infiltration of an external air, significant moisture gains from people and thermal bridges.

\subsection{Specific Differences in Microclimate Change between Selected Types of Buildings}

The division of tested sacral buildings into the small, medium and large type displays the following differences in the microclimate change between objects:

- In tested objects, the most considerable air temperature increases (caused by heat emission from people) are observed in the occupied zone of sacral buildings. Influence is often reduced by convectional raise but, in general, this emission is important as a useful heat gain, considering the aspect of achieving thermal comfort and the aspect of the building heat balance.

- The rise in temperature of the tested objects changes with the height above the floor level.

- The highest temperature rise is achieved in the human occupation zone (all types of tested buildings).

- In smaller sacral objects there is greater ability to design the microclimate by predicting temperature rise in case of people's presence.
- The rate of decrease in temperature depends on the use of the room after leaving it by people (windows and doors opening and at how long it lasts). The sacral buildings are often ventilated between the Masses.

- The effect of raising the temperature during use of objects depends on the number of persons staying, as well as on the duration of use of the object and the density of people in the space.

- The distribution of the temperature change caused by the emission of heat by persons is varied in both the horizontal plane of the room and at the different heights. The presence of heat sources, the unevenness of the density of the people's occupation in the space of the room, the air movement near the windows, influence the formation of temperature distribution.

- It has been observed that in the lowest and smallest objects (Type I objects) buildings microclimate deterioration is most common.

- On the basis of the achieved results, it was found that in the smallest objects there are heat gains which allow reaching the thermal comfort (in winter and during a whole heating season).

- In large objects, there is a cooler zone in the middle part (considering heights) of the room.

- It has been found that the considerable air temperature rise depends on some minimal number of people staying inside the room. It is possible to indicate the number of about 25 people. Then, about $50 \%$ of cases in objects of small volume cause a noticeable increase in temperature.

- The effect of a significant temperature increase with a minimal amount of persons causing a noticeable rise in temperature occurs within about 10 minutes after entry to the object and is maintained for about 30 minutes after leaving it by Mass attendants.

- Accumulation of air temperature increase caused by the presence of people can be seen in the Sunday successive Masses. In $90 \%$ of the cases, it results in a 
gradual increase in temperature. It is even up to $300 \%$ higher than in the case of a single Mass.

- Providing adequate ventilation, especially in small objects is necessary to avoid deterioration in air quality. In larger buildings, the amount of air available may be sufficient to ensure adequate air quality in room during the people's presence.

- The influence of the human heat emission on microclimate depends on ventilation intensity. In some cases, it is not necessary for buildings of a larger volume (especially in Type III objects).

\section{Conclusions}

The results of the research helped to improve some methods of assessment of the influence of the heat emission from people on the room microclimate. The preliminary assessment and conclusions are:

- There is direct dependence between number of people staying inside the sacral building and the air temperature growth;

- The human heat emission in tested cases was the considerable part of the heat balance of all types of investigated large-volume buildings especially in Type I objects;

- In the residential apartment buildings in all tested cases, right ventilation is needed. The heat and moisture gains from people are divided between individual dwellings;

- The useful heat emission should be reduced by the ventilation heat loss, but even after this reduction, there is still even a few dozens of watts per person as an effective heat gain;

- Sacral buildings, in general case, because of the significant heat gain from people can be designed as even unheated or passive buildings (considering climatic conditions in Poland);

- As an opposite case to the sacral buildings, in the residential apartment buildings poor ventilation often causes significant humidity growth and sick building syndrome risk (troubles with partitions and thermal insulation, as an effect of poor ventilation, badly performed thermo-modernization, thermal bridges, etc.). Nevertheless, the same situation can occur in sacral buildings because of the same technical problems and also because of low air temperature and high air relative humidity. It was observed in some cases in sacral buildings also and it led to the sick building syndrome, serious partitions damages and mold there.

Research on the large-volume buildings is still ongoing and newer results will be published next year with the precise assessment of the heat gain.

\section{Acknowledgements}

All tested sacral buildings were investigated thanks to the permission of the Roman Catholic Diocese of Płock.

\section{References}

[1] Fanger, P. O. 1974. Komfort cieplny. Poland: Arkady.

[2] Pogorzelski, J. A. 1976. Fizyka cieplna budowli. Warszawa: PWN.

[3] Recknagel, H., Sprenger, E., Hoffmann, W., and Schramek, E. 1994. Ogrzewanie i klimatyzacja. Poradnik. Gdańsk: EWFE.

[4] PN-EN 13187: 2001. Właściwości cieplne budynków-Jakościowa detekcja wad cieplnych w obudowie budynku-Metoda podczerwieni. Warszawa: PKN.

[5] Dz. U. 2002. nr 75 poz. 690 Rozporządzenie Ministra Infrastruktury z dnia 12 kwietnia 2002 r. w sprawie warunków technicznych, jakim powinny odpowiadać budynki i ich usytuowanie. Warszawa: Ministry of Infrastructure.

[6] PN-EN ISO 6946. 2017. Wersja angielska. Komponenty budowlane i elementy budynku. Opór cieplny i współczynnik przenikania ciepła. Metoda obliczania. Warszawa: PKN.

[7] PN-EN 12831-1. 2017. Wersja angielska. Charakterystyka energetyczna budynków-Metoda obliczania projektowego obciążenia cieplnego-Część 1: Obciążenie cieplne, Moduł M3-3. 2017. Warszawa: PKN

[8] Jelec, P. A. 2017. "The Selected Aspects of the Microclimate Change Caused by the Heat Emission from People Staying inside the Large-Volume Buildings." Presented at the International Multidisciplinary Scientific GeoConference SGEM, Varna. 

Heat Emission from People

[9] Jelec, P. A. 2017. “The Microclimate Parameters Change in the Occupied Zone inside Some Large-Volume Buildings with Significant Influence of the Heat Emission from People Staying Inside.” E3S Web of Conferences 19, 01015: EDP Sciences.

[10] Jelec, P. A. 2017. "The Selected Aspects of the Microclimate Change inside the Sacral Buildings Caused by the Heat Emission from People.” International Multidisciplinary Scientific GeoConference SGEM, Vienna.

[11] Wolski, L., Jelec, P. A., Grabarczyk, S., Krajewska, A., and Kamiński, A. 2006. Fizyka obiektów sakralnych-pod kierunkiem Leszka Wolskiego. Warszawa: Polish Academy of Sciences. 